\title{
Reflexões de um roteirista
}

\author{
Jean-Claude Carrière*
}

\section{RESUMO}

O presente texto é a transcrição parcial de um seminário ministrado por Jean-Claude Carrière no Ateliers des Arts em março de 1983. Percebemos aqui o inicio de reflexões sobre o fazer cinematográfico que serão aprofundadas mais tarde em A Linguagem secreta do cinema (publicado no Brasil em 1995) O tema principal das reflexöes de Carrière é o métier que ele domina como poucos: como contar uma boa história.

\section{RÉSUMÉ}

Le texte ci-dessous c'est la traduction en portugais de la transcription partielle d'un séminaire donné par Jean-Claude Carrière dans le cadre des Ateliers des Arts en mars 1983. On perçoit dans ce texte-ci le germe des réflexions qui seront approfondies dans The Secret language of film. Le sujet principal des reflexions de Carrière c'est le métier sur lequel il a un domain comme peu des écrivains el scénaristes: comme raconter une bonne histoire.

Traduzido por Ignácio Doito Neto, roteirista, mestre em Teoria Literária pela UNICAMP, autor de Entreatos - o teatro em Curitiba entre 1981 e 1995, e Contracenas - o teatro em Curitiba contado por seus artistas. 


\section{O que é um roteiro?}

\section{Um texto em mutação}

Um roteiro pode ser comparado a uma ferramenta de alquimista. Uma passagem. Uma transmutação. Todos aqueles que, sobre um tablado, em um estúdio, participam desta transformação muito lenta, muito difícil, tão árdua quanto a busca da pedra filosofal - seja ele o último estagiário que traz os sanduíches ou o 'mestre da obra' - são os operários deste ato de feitiçaria. Eles trabalham neste antro, neste cadinho mágico que é o cinema, que irá transformar um 'objeto' escrito em 'coisa' filmada. O roteiro é principalmente isso, o instrumento de uma passagem, uma etapa crisálida. Se tivesse que definir o roteiro, é o que eu poderia dizer... Um texto portador de um outro estado... Palavras geradoras de imagens e sons.

\section{Um texto livre}

Nunca digo 'Uma das regras fundamentais do roteiro é...'. Acho que não existe nenhuma regra neste campo. Os roteiristas podem imaginar tudo, fazer tudo. A única certeza, a única exigência é que aquilo tem que funcionar... e ai nenhum pressuposto divino ou humano pode ditar essa

100 ou aquela forma. Dito isto, existem princípios que se aprendem e nos quais se acredita porque sabemos que quando não os aplicamos o filme não fica tão bom quanto poderia. Me parece essencial e evidente 'nunca anunciar o que será visto, nunca contar o que se viu'. Isso parece simples e pueril, um novo ovo de Colombo. E, no entanto, quando vamos ao cinema, os personagens comentam a ação, discorrem sobre a imagem quando é completamente inútil ou, pior ainda, anunciam e expõem o que vai acontecer, aquilo que nos será mostrado. É uma perda de tempo considerável, uma redundância. Evitá-la é difícil e dá muito trabalho, mas é uma regra que me imponho e cada roteirista cria sua própria exigência. Isso força a não ceder à facilidade da narrativa e a buscar e imaginar soluções narrativas que, de outro modo, não teriam sido confrontadas.

\section{Um texto que não é uma narrativa}

Todos nós fomos educados na tradição da tragédia clássica que se baseia na narrativa. Isto faz parte de nossos 'genes' e é difícil desprenderse deles, na verdade impossivel como mudar de raça. No período da tragédia clássica, se narrava, não se mostrava. Fazia-se assim por razões 
de 'bom gosto', de conveniência. Agora, quando as contingências não são mais as mesmas, ainda nos resta alguma coisa que não conseguimos esquecer. Não estou afirmando que não há necessidade de narrativa no cinema. Algumas vezes é até interessante narrar alguma coisa que não vimos. Em $A$ via Láctea, que escrevi com Buñuel, um personagem conta um milagre e para mim é uma das melhores cenas do filme... Buñuel e eu nunca haviamos experimentado isso e um dia dissemos 'E se escrevêssemos uma narrativa cinematográfica?'... Imaginamos que alguém se senta perto de uma lareira, rodeado por uma platéia c começa a contar... E que o que ele diz, o que sugere não é nem uma narração romanesca nem um texto teatral, mas pertence ao mundo cinematográfico... O cinema não é literatura. Isto me parece muito importante. A literatura é talvez o maior perigo que ameaça o roteiro, o cinema: é preciso que desconfiemos das palavras muito bonitas que sào utilizadas, das frases muito bem construidas: elas não têm equivalência na tela; elas se referem a um outro registro, o do estilo escrito e não à linguagem visual. Somos tentados sempre colocar no papel 'que reina em uma peça uma atmosfera lúgubre' ou que 'os personagens têm um ar de contentamento'. O que isso quer dizer? É preciso que um roteirista seja extremamente honesto com o filme que vai nascer de suas palavras. Ele não pode escrever algo que não vai acontecer, que não tem relação com o que o expectador irá ver.

Se podemos escrever que 'Georges Swamm acorda de mau humor', é preciso saber primeiro o que, sem essa indicação, não é possivel, ou menos dificil. Em seguida, isso pode ser indicado, mas é preciso que este estado de espírito seja traduzido na tela, o que não é simples. Mas escrever 'que ele acorda pensando em Odette' pertence apenas à literatura, que vem naturalmente sob a pena quando é preciso afastar-se dela. A experiência me ensinou outras coisas no que diz respeito à escrita técnica de um roteiro.

\section{Um texto ligado ao tempo}

Não é preciso narrar longamente una açào breve e brevemente uma ação longa. O tempo de leitura de un roteiro deve corresponder quase ao tempo de projeção do filme. As duraçōes devem ser iguais. Ler um rotejro em voz alta - ação e diálogos - por alguns minutos não deve tomar mais ou menos tempo que o que se passa para ver o filme. Não é preciso descrever em vinte e cinco linhas a queda de alguém que cai de uma janela nem despachar em uma frase a atitude de um personagem que, debruçada nessa mesma janela, está sonhadora e triste, espera por alguém ou olha a paisagem durante muito tempo. Nesse caso, convém definir com precisão o que se vê e fazer sentir de uma maneira indireta o tempo que passa. 
Em suma, é preciso que a escrita seja equivalente e paralela ao tempo cinematográfico.

\section{Um texto próximo à imagem}

Sou roteirista há 20 anos e tenho constatado - devido aos fatos - uma evolução na escrita de roteiro. Antes ela era muito mais técnica, precisa. Era necessário dar muitas indicações de cenário, de lentes, até mesmo de diafragma. Hoje, tudo isso desapareceu em grande parte e o roteirista não está mais ligado desse modo a uma escrita que inclui uma découpage técnica, pois a filmagem se faz mais comumente em cenários naturais aos quais devemos nos adaptar no próprio momento.

Mas permanece na escrita de um roteiro uma certa maneira de indicar o que eu chamo uma découpage inconsciente ou subterrânea. $\mathrm{O}$ simples fato de iniciar novo parágrafo evidencia isso. O conteúdo das frases também.

Se digo "uns trinta estudantes estão reunidos em uma sala com poltronas negras da escola de cinema', isso implica, sem necessidade de maiores especificações, uma panorâmica. Se escrevo 'na primeira fila, uma estudante morena com cabelos curtos toma notas com uma caneta azul', isso indica automaticamente um close.

Iniciar um novo parágrafo ritma inconscientemente a leitura e dá indicações preciosas. À primeira vista, não nos damos conta que existe uma découpage, mas existe, e a leitura não é obstruída e sobrecarregada de

102 indicações técnicas. Se leio 'em uma pequena mesa, dois homens estão sentados. Um fala e tem uma barba grisalha, e o outro, os braços cruzados e está ouvindo', eu vejo um plano médio. Se leio 'sua mão leva um copo d'água até seus lábios', eu sei que se trata de um close-up.

Se queremos indicar um travelling unindo esses dois planos - plano médio e close-up - basta escrever essas duas ações sem interrupção, quer dizer, 'dois homens estão sentados em uma mesa. Um fala, o outro escuta. A mão do homem barbudo pega um copo e aproxima de seus lábios'. Inconscientemente, fiz um zoom e antes um travelling, porque não abri novo parágrafo.

Se, em compensação, eu abro um novo parágrafo, por esse simples fato de escrita, indico um corte, uma mudança de plano.

Quando se trabalha com um diretor, quando imaginamos em dois uma cena, acontece um outro fenômeno. Acontece uma espécie de comunicação visual que se estabelece, que mantém a découpage inconsciente induzida no que acabamos de perceber - iniciar novo parágrafo ou não, escrever essa ou aquela frase.

Misteriosamente, os dois colegas vêem a cena com as mesmas disposições. Com Buñuel, isso acontecia constantemente. Se eu escrevia, por exemplo, 'Alguns expectadores estão na sala. Pela porta enfeitada com papel de parede azul acaba de entrar um homem moreno, 
vestido com um pulôver, que vai se sentar'. Isso queria dizer - minha mudança de parágrafo - que eu tinha me colocado na porta para ver a entrada desse personagem. Quando começávamos a trabalhar essa cena e eu desenhava a tomada, se eu perguntava 'Luis, de que lado do cenário é a porta?', ele me respondia, por exemplo, 'à sua esquerda' e isso sempre correspondia ao que eu havia imaginado. Isso está relacionado ao gesto que fazemos, às atitudes que tomamos, mas também a uma comunicação quase telepática que se estabelece entre duas pessoas que trabalham há alguns dias ou semanas juntos.

\section{Existe história e história}

Existem muitas maneiras de abordar uma história. Podemos classificar as narrativas em gênero 'histórico', épico, cômico, sabendo que estes rótulos são sempre inúteis. Podemos também tentar definir uma história segundo o público para o qual nos dirigimos.

Eu prefiro me situar em um outro plano. Creio que existem apenas três tipos de histórias.

A história contada por alguém que a conhece para pessoas que também a conhecem. Esse tipo de narrativa possui raizes muito ancestrais e é o mais difundido. É da mesma familia do trabalho dos contadores de histórias. Penso sempre naqueles da Amazônia que têm por tarefa contar os eventos míticos que determinaram o nascimento da tribo. O que eles dizem, todos os espectadores já conhecem. Mas o que é importante é a maneira como eles contam, a maneira de introduzir suas personalidades aos acontecimentos. Os mesmos fatos muito precisos assumem uma outra coloração conforme é este ou aquele contador que se encarrega de contar. Danton' pertence a este tipo de história. O homem que ele é, o que lhe acontece não é uma revelação. 90\% dos expectadores sabem que ele vai se opor a Robespierre e que será guilhotinado. O que vai thes interessar no filme Danton que coloca em cena um homem cujo destino eles conhecem muito bem? É preciso segurar sua atenção não por meio de peripécias - que já estão enumeradas - mas pela maneira de apresentar a narrativa, o ângulo da tomada e o trabalho do ator.

Existe também a história contada por quem a conhece para aqueles que não a conhecem. Mais de $50 \%$ dos filmes que vemos pertencem a essa categoria, é evidente. Se escrevo um roteiro de um filme policial, eu conheço o culpado, conheço o assassino e sei como o desfecho vai acontecer. Os espectadores, pelo menos em principio, ignoram tudo isso. Hitchcock, que é o mestre desta segunda categoria de narrativa, dizia: 'não conte o fim'. É o que podemos chamar 'a história chtt' ou história 'dedos sobre os lábios'.

Este gênero de narrativa também possui raizes muito antigas. $\mathrm{O}$ teatro, 
a arte dramática, têm origens sagradas, estão ligados ao religioso. Mas a tragédia grega pertence mais à primeira categoria. Aqui, encontramos o que apareceu com o romance, quer dizer, uma história que foi escrita por alguém que a inventou e é descoberta pelos leitores que a ignoram e penetram nela página após página, acontecimento após acontecimento.

Por último, existe o terceiro tipo de narrativa. Alguém conta uma história que não conhece a pessoas que não a conhecem mais que ele. Isso pode ser resumido em uma única palavra: 'improvisação'. Aí também as origens remontam à noite dos tempos. O teatro a tem praticado desde os primórdios e, na tela, Godard ou Ferreri trabalham dessa forma e são os cineastas do terceiro tipo. No momento em que Jean-Luc Godard diz "filmando", ele não sabe realmente o que vai se passar. Ele diz 'é preciso evitar chegar antes de ter partido' e a primeira questão que ele coloca sempre é 'o que está acontecendo?'. No momento em que 'estão rodando' acontece alguma coisa que não aconteceria durante os ensaios. Existem evento e fenômeno novos. Ele os espera e os utiliza.

Ferreri raramente faz uma tomada duas vezes. O que lhe parece importante é o que ele captou naquele momento preciso. Acontece de ele suprimir se a tomada não ficou boa. Cada vez, bem entendido, ele tem uma idéia do que quer, mas não sabe o que vai ter e se deixa levar pela descoberta.

Para citar um belo exemplo do que a improvisação pode trazer a um espetáculo, é preciso citar Les maîtres fous, de Jean Rouch, que Peter Brook também considera um filme emblemático. Aí, trata-se de um happening, uma palavra decomposta que modifica todo seu sentido: o que acontece em um momento de transe, quando um ator está tão completamente possuído que esquece de si mesmo e se torna aquilo se supõe que está representando? É preciso ver e rever este filme para compreender bem o que a improvisação pode dar como dimensão nova a um espetáculo.

Raoul Ruiz, com quem eu falava um dia da minha maneira de classificar as histórias em três tipos de narrativas, me respondeu sob a forma de provocação e de brincadeira que existe ainda uma quarta 'uma história contada por pessoas que não a conhecem para pessoas que a conhecem'. Eu pedi que me desse um exemplo e ele me disse 'Todos os cineastas da América Latina ou do Terceiro Mundo vêm a Paris. Fazem o IDHEC $^{2}$, aprendem a fazer cinema à européia e em seguida retornam a seus países. Resolvem contar uma história típica deles, mas fazem em um estilo europeu. $\mathrm{O}$ que faz com que coloquem em cena uma história que eles esqueceram, perverteram, traíram, transformaram e a contam para pessoas, para espectadores que a conhecem muito bem, mas que simplesmente não a reconhecem mais'. 


\section{O ritmo e o tempo}

\section{Uma outra escritura}

Se escrevo em um roteiro 'na manhã seguinte, Charles Swann acorda pensando em Odette', é uma frase literária que não possui nenhuma equivalência cinematográfica. Cada palavra contém uma impossibilidade: 'o dia seguinte': como indicar no cinema que estamos no dia seguinte? 'De manhã' é menos simples do que pensamos. 'Charles Swann'; se não pronunciei esse nome antes, ninguém saberá quem ele é: será simplesmente um homem em sua cama. E 'pensando em Odette' não é imaginável. Podemos mostrar um ator que está refletindo, mas não podemos mostrar alguém que está pensando. Se não conseguimos comunicar um pensamento preciso, às vezes tentamos sugerir de modo sutil aquilo que um personagem está pensando. Simplesmente mostrando-o e abstendo-se de falar de suas impressões ou de suas preocupações.

Mas de um modo geral 'o pensamento é a noite do cinema'...

É preciso lembrar sempre que o público é mais passivo no cinema que no teatro. A imagem na tela se impõe com mais força e realismo que uma cena de teatro. Quando um diretor não se dá conta da faculdade de imaginação de um público de teatro, ele vai inevitavelmente ao fracasso. No cinema, o espectador está na sombra e está disposto a receber imagens. A partir do momento que uma imagem é fotografada, que é a própria definição do fotograma, ela é recebida como verdadeira. É por isso que o fantástico, a violência, o horror possui tanto impacto: acreditamos no que vemos. A tela é portadora de verdade. O cinema nos transforma em São Tomé: vimos, acreditamos. No teatro, ao contrário, permanecemos sempre no teatro. Isso não quer dizer que a emoção sentida seja fraca, mas ela nos atinge de um modo diferente.

\section{A importância do tempo}

Fazer perceber o desenrolar do tempo é outra dificuldade. Isso se transforma em um instransponivel quebra-cabeça quando é preciso indicar que se passam 15 dias ou três semanas e encontrar um ritmo que permita contar uma história pelo calendário. Por outro lado, devemos estabelecer dentro do roteiro uma espécie de continuidade, de 'falso ritmo', e separar o que chamamos 'o tempo cinematográfico', tempo que é para mim o problema número um desta escritura. O tempo cinematográfico se diferencia do tempo romanesco e do tempo teatral. 


\section{As noites e os dias}

Um dia, eu falava de Danton com Wajda. Eu disse a ele 'me parece, depois de tantos anos de trabalho, que uma das coisas mais importantes em um filme é a alternância de noites e dias'. Não que seja necessário uma noite para uma noite e um dia para um dia, pois o dia cinematográfico não tem nada a ver com a descrição de tudo o que se passa durante 24 horas. Podemos escrever 'interior' do Palácio do Congresso. 'Dia' e em seguida 'interior. Hôtel Arenberg. Dia'. Será um dia cinematográfico, mas a cena do hotel poderá se passar três semanas depois. Dentro de um dia 'tela', podemos colocar muitos dias da vida real, misturar o tempo.

Para as noites, é mais dificil. Temos todos na memória certos filmes noir americanos que se passam quase que exclusivamente durante a noite, nos quais uma noite sucede a outra, continuidade que é mais difícil e acrobática de estabelecer que a dos dias. Pois sei, sem poder explicar, que uma noite cinematográfica dificilmente pode conter muitas noites reais. Ao contrário do que é possível com os dias.

Mas o mais importante é a relação, no interior de um mesmo roteiro, da sucessão de noites e dias. Isso dá um ritmo inconsciente que não é percebido, que não é preciso acentuar, mas que funciona com energia. Esse ritmo é essencial: todas nossas atividades, nossa vida, são definidas por ele. Romper com isso condena ao mal-estar, ao fracasso.

106 Acabo de trabalhar com Daniel Vigne em um filme, Le Retour de Martin Guerre. A ação se passa durante três ou quatro meses. É indispensável estabelecer desde o início o número de noites contidas em um roteiro. Não podemos escrever um roteiro que dura muitos meses somente com duas noites. É melhor que sejam 6 ou $7 \ldots$ sem chegar a abordar as 90 ou 120 que corresponderiam à realidade!

Observei, sem nunca ter tido a teoria, que as passagens do dia e da noite indicam uma mudança muito rápida. Também é bom alterná-los de modo regular - se isso é possivel - para que o mesmo intervalo separe as noites umas das outras. Isso ajuda a encontrar uma respiração, um ritmo que parece natural porque está de acordo com o desenrolar do tempo na realidade, com a passagem das estações. Isso, posso dizer, é quase uma receita.

Quando eu falava para Wajda de tudo isso, ele foi logo interrompendo e me disse 'Eu precisei de 20 anos para descobrir isso'. Esse ritmo é muito importante. Se ele não funciona ou funciona mal, cria uma espécie de caos que pode ser interessante se o dominamos, se o organizamos, se brincamos com ele. Um filme não é um rio que corre com regularidade. Nele podem existir quedas, cascatas, redemoinhos. Mais uma vez não existe qualquer regra, mas é preciso saber que, quaisquer que sejam o estilo e o ritmo de seu filme, esta alternância de dias e noites é fundamental. 


\section{Encontrar o ritmo}

Todo ritmo é bom. Toda quebra de ritmo é perigosa. Ela pode ser às vezes extraordinária se é bem feita, pois desperta o interesse.

Todo ritmo é bom, seja ele rápido, lento ou moderado. Mas é importante não errar o ritmo. Assistimos comédias devastadas porque o diretor pensava que esse gênero implicava obrigatoriamente o movimento irregular, o acelerado, a rapidez, que se a câmera girasse rápida, seria muito mais engraçado do que se funcionasse em velocidade normal. Laurel e Hardy nos ensinaram exatamente o contrário. Eles são, juntamente com Raoul Walsh, os inventores do cômico lento, do cômico vindo do circo, do cômico em que não se acelera... e embaixo da lona milhões e milhões de pessoas riem há gerações.

A questão do ritmo não está apenas ligada ao assunto, mas ao ator e ao resultado antecipado. Vi Tati, no dia de estréia de As férias de Monsieur Hulot, espantado, na cabine de projeção do cinema Normandie, refazendo a montagem. Chaplin dizia que nunca sabia quanto tempo deveria permanecer em um efeito cômico no fim de uma gag. Buñuel conheceu Chaplin muito bem. Eles se viam muito em uma época que Luis estava passando por dificuldades financeiras. Buñuel inclusive tentou vender algumas gags a ele. Um dia, Chaplin o convidou para uma pré-estréia de Luzes da cidade, filme onde há a famosa cena em que ele engole um apito. Ele tem un soluço e está assoviando. Buñuel, como os outros espectadores, riu muito... no início, porque a gag durava 23 minutos, duração que Chaplin achava perfeita. Buñuel me contou 'Depois de 3 ou 4 minutos, frente a essa repetição desmesurada, nós nos olhamos, em seguida olhamos nossos relógios e no final da seção, dissemos a ele que era muito interessante, mas que havia aquela cena que não acabava nunca'. Chaplin, que, entretanto, sabia fazer filmes, ficou com um ar muito surpreso. Ele não tinha se dado conta que a duração era inadmissivel. Foi preciso toda a insistencia de Buñuel e de outros para reduzir a gag a um tempo razoável... normal. Embora a noção de normalidade seja muito elástica uma vez que o que faz um espectador rir durante um certo tempo poderá aborrecer outro rapidamente. Uma platéia é uma mistura.

\section{São necessários tempos mortos?}

Quando me colocam essa questão, penso sempre na cena de acampamento em um western... esse tempo de suspensão, da qual algumas vezes sentimos a obscura necessidade que se assemelha àquela da noite. Essa cena não existe apenas neste tipo de cinema. Transposta, a encontramos em todos os filmes. Ela está presente em Claude Saudet quando ele volta com Piccoli e Schneider. Trata-se do momento em que a ação pára e sentimos a necessidade de comentá-la, determinar as coordenadas. Os personagens donmem se possivel uns 
nos braços dos outros e, que um índio malvado ou o marido ciumento esteja escondido atrás de uma moita ou de um outdoor, o que importa é que seja um momento de respiração e não de tensão.

Essa cena de acampamento é um tempo morto? Não creio, pelo menos não no sentido negativo. Ela faz parte da estrutura da narrativa e da necessidade que os espectadores têm de fazer uma pausa. Um tempo morto também não é uma moldura vazia ou uma cena que dura excepcionalmente muito tempo. Neste caso podemos de preferência falar como dizemos no teatro 'colaboração com o público'. O encenador deve se perguntar às vezes 'o que é que permite à imaginação de um espectador brincar no mesmo tempo que a minha?' Losey em Accident faz com que os personagens saiam de cena e nos deixa por um momento em um cenário vazio, seja um interior ou um caminho na zona rural rodeado de árvores. Se formos espectadores atentos e interessados, esta imagem não será vivenciada como nada: ela faz vibrar em nós tudo o que a cena anterior significava, continuamos a contar para nós mesmos a história dos personagens que acabam de sair. Mas esse qualquer coisa que continua em nós, somos nós, o público, que o trazemos, não é Losey. Losey nos ofereceu a ocasião de sonhar naquele momento. A ocasião de reunir nossos sentimentos, a ocasião de imaginar o que continuam a fazer e a dizer os personagens que não estamos mais vendo. Isso é muito, muito bom.

Mas será um tempo morto, esse momento em que bruscamente a ação pára e quando o que passou em um olhar ou um gesto é deixado para a interpretação e emoção de cada expectador? Não acho.

\section{O conteúdo da imagem}

\section{Uma linguagem de olhare gesto}

Fui rever La marche nuptiale, de Eric von Stroheim. É um filme de que gosto muito. Me perguntei como tinha sido escrita no roteiro a cena da sedução a cavalo - ela é bastante conhecida - quando, enquanto uma missa solene está sendo celebrada na catedral, Stroheim, que no filme interpreta um personagem que comanda um esquadrão de cavaleiros austríacos nesta cidade de guarnição, seduz uma jovem que vê passar seu cavalo e seu regimento. Ela está no meio da multidão com seu noivo, um açougueiro muito rude, e seus pais. É uma cena que dura 15 minutos: nem uma palavra é trocada. Não há nada além de olhares, gestos, sorrisos muito discretos.

Como isso foi escrito, narrado, minuciosamente calculado no papel? Tudo acontece no olhar e cada olhar é diferente. Existem os olhares da jovem e ela está com sua cabeça quase na altura do joelho de Stroheim. Ele quer perguntar a ela se ela é casada. Ele está com sua espada na mão, ele a baixa e também os olhos, ele convida seu olhar a fazer o mesmo movimento. Há um contracampo da jovem cujo olhar baixa até a mão de Stroheim, a mão que faz alguns gestos, que a jovem não entende, isso se lê em seus olhos. Então, ele 
cruza as mãos e em uma outra atitude, um outro movimento, tenta perguntar a ela 'você é casada?'

É uma cena fantástica, muito erótica. Como traduzir em um roteiro o que não é uma linguagem de diálogo, mas de fisionomia, de atitude? Acho que houve uma découpage muito precisa, quase desenhada. Não podemos deixar ao acaso da montagem as direções do olhar, os olhos da jovem que vão do rosto até a mão. Isso deve estar rigorosamente previsto.

\section{O cassetete de Hitchcock}

Hitchcock colocava os problemas do cinema de um modo muito concreto. Ele se perguntava, por exemplo, e ele achava isso fundamental, se, quando uma pessoa caminha por uma rua na qual depois da esquina alguém a espera com um cassetete, é preciso mostrar ou não o homem com o cassetete. Durante toda a vida ele se colocou esse problema, como Chaplin nunca parou de se perguntar quanto tempo deveria durar a gag do apito.

A maneira como estou falando dessas coisas pode parecer simplificar essa questão, ela não continua menos central. É necessário mostrar os suspenses: filmar o homem que caminha pela rua, pára, compra um jornal, enquanto o outro, constrangido pelos transeuntes, esconde seu cassetete ou jogar com o prodigioso efeito de surpresa de um golpe de cassetete que não era esperado. É entre esses dois pólos, com todas as nuances que eles implicam, que trabalha o cinema de Hitchcock. Ele e Lubitsch se comportam como romancistas do século XIX, eles são os mestres absolutos de seus personagens.

En To be or not to be, Lubitsch passa de um personagem a outro, de um cenário a outro em função do que espera da reaçio do público. Isso retoma e prolonga a questão colocada por Hitchcock: em que momento o público deve estar antecipado em relação ao personagem, em que momento ele deve estar atrasado.

Em um filme policial, o detetive possui uma informaçĩo que precede a do espectador. Ele sabe de coisas, mas nos oculta até a revelação final. Ele faz um certo número de operações misteriosas, de colocações que nos mostram que ele tem una idéia. Por outro lado, no exemplo de Hitchcock, se vemos o homem com o cassetete estamos adiantados em relação ao detetive e à narrativa.

\section{O bom lugar do clichê}

Hitchcock dizia também, em uma outra esfera, 'Mais vale partir de um clichê do que terminar em um'. Quando procuramos uma idéia original, que damos tratos à bola para encontrar uma situação que nunca foi contada e a encontramos, começamos por festejar e nos parabenizar por termos inventado um truque extraordinário. Em seguida nos perguntamos 'Será que os 
expectadores vão aceitar isso?' Então começamos a elaborar, a encontrar ajustes, em suma, a reduzir o novo, e terminamos com um clichê.

Isso aconteceu com Jean Lotte há uns vinte anos. Ele propôs a um produtor de rodar um filme sobre a vida dos santos dos primeiros séculos da Igreja. Ele conhecia muito bem o assunto e havia publicado um livro a respeito. Os dois concordaram que é uma história extraordinária, que nunca tinha sido filmada, portanto deveria ser feita. Eles envolveram um roteirista e todos trabalharam por mais de seis meses. O filme foi de fato filmado, mas, de mudança em mudança, não se tratava mais de uma história santa, mas de uma série noir com Eddie Constantine que se passava na Madrid de nossos dias. Eis o caminho de um roteiro. De tanto se perguntarem sobre por que um filme tão longe de nós, de se perguntar qual personagem contemporâneo poderia ser o mais próximo de um santo de antigamente e descobrir que seria um detetive particular, sem nenhuma pressão do produtor, eles chegaram a fazer um filme completamente banal partindo de uma idéia bem original.

Se, por outro lado, como Hitchcock e Lubitsch, partimos de uma situação melodramática clássica e desenvolvemos essa idéia, ao fazermos um exercício de aprofundamento, ao introduzirmos pouco a pouco elementos que irão, digamos, pervertê-la, torná-la interessante, temos mais chances de chegar a um filme original do que se, desde o início, pensamos que iremos fazer algo que nunca foi visto.

Quando partimos de uma originalidade importante ou de uma grande

110 novidade, contra nossa própria vontade, estamos nos protegendo. Estabelecemos estruturas de pensamento, medos, freios que agem e nos bloqueiam sem nos darmos conta.

\author{
Notas \\ ${ }^{\prime}$ Filme de Andrej Wajda, roteiro de Jean-Claude Carrière. \\ ${ }^{2}$ Institut des Hautes Études Cinématographiques (N.T.)
}

\title{
Palavras-chave \\ 1. Roteiro \\ 2. Jean-Claude Carrière
}

